JURNAL GIZI DAN DIETETIK INDONESIA

Vol. 4, No. 2, Mei 2016: 88-96
Tersedia online pada: http://ejournal.almaata.ac.id/index.php/IJND DOI : http://dx.doi.org/10.21927/ijnd.2016.4(2).88-96

\title{
Formulasi bubur bayi MPASI yang diperkaya hidrolisat protein ikan lele dumbo (Clarias gariepinus)
}

\author{
Formulation of complementary feeding porridge enriched with hydrolized catfish protein (Clarias \\ gariepinus)
}

Veriani Aprilia ${ }^{1}$, Febrina Suci Hati ${ }^{2}$

\begin{abstract}
Background: Malnutrition become the problem in Indonesia. Complementary feeding has the role in solving it. Most of commercial complementary feeding are enriched by vegetable protein, whereas animal protein has more complete amino acid and better digestibility. Unfortunately, consuming animal protein often raises concern because of its allergenicity. Catfish (Clarias gariepinus) can be used as a source of high animal protein in the diet that may solve the nutritional problem after reduction of its allergen.

Objectives: To develope formulate of complementary feeding porridge enriched with hydrolized protein from catfish muscle.

Methods: This was experimental study. HPIL and HPIK was enzymatic hydrolized products of catfish using crude and commercial papain, respectively. Overall and partial hedonic test used 23 mothers as panelists, then selected formula were tested its acceptance by 9 babies using face scale. Nutrient content of porridge were analyzed for protein, carbohydrate, fat, protein, and water.

Results: Hydrolysis of catfish using papain made the changes in color, taste, and aroma. The bitter taste limited the uses, maximum amount was $25 \%$. Porridge with the addition of HPIK were chosen by mothers and babies panelists, whereas HPIL did not. Protein content of formulated product were lower than commercial product, but carbohydrate and fat content were higher.

Conclusions: Porridge formula with addition of $25 \%$ HPIK my be developed as alternative product of complementary feeding.
\end{abstract}

KEYWORDS: protein, papain, catfish, protein hydrolisate, complementary feeding

\begin{abstract}
ABSTRAK
Latar belakang: Kekurangan gizi masih menjadi masalah di Indonesia. MPASI memiliki peran penting dalam mengatasi masalah tersebut. MPASI pada umumnya diperkaya oleh protein nabati, padahal protein hewani mengandung asam amino dan daya cerna yang lebih baik. Namun demikian, protein hewani meningkatkan risiko alergi pada bayi. Lele (Clarias gariepinus) dapat dijadikan alternatif sumber protein hewani karena ketersediaan yang banyak dan harganya yang murah. Diperlukan suatu teknologi untuk mengurangi tingkat alerginya dan formulasi yang tepat dibutuhkan agar dapat diterima oleh bayi.

Tujuan: Formulasi bubur bayi MPASI yang diperkaya hidrolisat protein ikan lele dumbo.

Metode: Jenis penelitian ini adalah eksperimental. HPIL dan HPIK merupakan hidrolisat protein ikan lele dumbo yang masing-masing dihidrolisis secara enzimatis menggunakan enzim papain kasar dan papain komersial. Uji kesukaan keseluruhan dan parsial menggunakan 23 panelis ibu, kemudian formula terpilih diujikan daya terimanya oleh 9 bayi menggunakan skala raut muka. Uji nilai gizi bubur bayi meliputi kadar protein, karbohidrat, lemak, protein, dan air.

Hasil: Proses hidrolisis kimiawi protein ikan lele dumbo menggunakan enzim papain menyebabkan perubahan warna, rasa, dan aroma produk. Adanya perubahan sifat tersebut menyebabkan penambahannya ke dalam formulasi bubur MPASI hanya sampai kadar 25\%. Di atas kadar tersebut, produk berasa pahit.
\end{abstract}

\footnotetext{
${ }_{1}$ Program Studi S1 IImu Gizi, Fakultas IImu-IImu Kesehatan, Universitas Alma Ata, Jl. Ring Road Barat Daya No 1, Kasihan, Tamantirto, Bantul, Yogyakarta, email: aprilia.triwanto@gmail.com

2 Program Studi D-3 Kebidanan, Fakultas IImu-IImu Kesehatan, Universitas Alma Ata, Jl. Ring Road Barat Daya No 1, Kasihan, Tamantirto, Bantul, Yogyakarta
} 


\begin{abstract}
Hasil uji sensoris produk formulasi HPIK dapat diterima oleh panelis ibu dan bayi, sedangkan produk HPIL tidak. Kandungan protein produk formulasi lebih rendah dibanding bubur komersial, namun kandungan karbohidrat dan lemak lebih tinggi.

Kesimpulan: Formula bubur bayi dengan penambahan 25\% HPIK dapat dikembangkan menjadi alternatif produk MPASI.
\end{abstract}

KATA KUNCI: protein, papain, lele dumbo, hidrolisat protein, MPASI

\section{PENDAHULUAN}

Kekurangan gizi pada anak balita (bawah lima tahun) masih menjadi masalah besar di negara berkembang, khususnya Indonesia. Data yang dikeluarkan oleh Direktorat Kesehatan dan Gizi Masyarakat (2012) dalam Riskesdas (riset kesehatan dasar) tahun 2010 menyebutkan bahwa prevalensi kurang gizi dan gizi buruk (berdasarkan pengukuran berat badan menurut umur) pada balita mencapai $17,9 \%$ dan 4,9\% (1). Masalah gizi ini merupakan akibat dari berbagai faktor, salah satunya adalah konsumsi makanan yang tidak memenuhi prinsip gizi seimbang yang apabila terjadi pada 1.000 hari kehidupan pertama seorang anak (sejak hari pertama kehamilan, kelahiran bayi, sampai bayi berusia 2 tahun) dapat menimbulkan efek yang permanen. Oleh karena itu, peran makanan pendamping ASI (MPASI) menjadi sangat penting.

MPASI dianjurkan mulai diberikan saat bayi berumur 6 bulan, karena sebelum usia tersebut imunitas tubuh bayi terhadap zat penyebab alergi (alergen) belum optimal. Banyak MPASI beredar di pasaran dengan zat gizi yang cukup, bahkan diperkaya dengan berbagai zat fungsional yang menambah nilai cerna di dalam tubuh bayi, seperti penambahan prebiotik, probiotik, dan lain-lain. Produk tersebut pada umumnya dibuat dari bahan utama beras atau serealia yang diperkaya dengan protein nabati, bukan protein hewani (2-4). Padahal protein hewani mengandung asam amino serta vitamin dan mineral yang lebih lengkap, serta mengandung asam lemak jenuh dan kolesterol yang dibutuhkan untuk perkembangan fisik dan otak balita (5). Protein hewani juga dilaporkan lebih mudah disintesis dalam tubuh dan mampu meningkatkan massa otot (5). Namun demikian, adanya alergen pada produk hewani menjadi pembatas penggunaan protein hewani, di samping alasan ekonomis (harga yang lebih tinggi dibandingkan dengan produk nabati).

Lele (Clarias gariepinus) merupakan salah satu sumber protein hewani yang saat ini banyak dibudidayakan dan mudah diperoleh di Indonesia. Namun demikian, kandungan protein yang bersifat alergen (contoh: parvalbumin) dapat mengurangi tingkat konsumsi ikan ini. Hidrolisis protein merupakan salah satu cara untuk menurunkan alergen. Melalui hidrolisis, molekul protein yang tidak dikenal oleh tubuh (bersifat allergen), akan dipecah menjadi molekul yang lebih kecil. Hidrolisis protein secara kimiawi memiliki kelemahan dapat menyebabkan kerusakan asam amino, sehingga cara enzimatis saat ini dinilai paling efisien. Hidrolisat protein ikan lele dumbo (HPIL) merupakan salah satu produk pangan yang dihasilkan dari hidrolisis protein daging ikan lele dumbo menggunakan enzim. Widadi (6) melaporkan bahwa dengan adanya reaksi enzimatis, kandungan protein HPIL meningkat jika dibandingkan lele dumbo segar, masing-masing $53,29 \%$ dan $16,2 \%$ (7), kecernaan protein lebih baik, dan konsentrasi asam-asam amino yang dihasilkan lebih lengkap (6). Hasil penelitian Aprilia dan Suci Hati (8) membuktikan bahwa HPIL yang dibuat secara sederhana menggunakan enzim papain kasar dapat mengurangi tingkat alergenitasnya.

Untuk aplikasi HPIL pada produk pangan, terutama MPASI, diperlukan formulasi khusus karena produk hidrolisat seringkali menyebabkan makanan berasa pahit (9). Beberapa syarat pembuatan MPASI juga perlu dipenuhi, yang meliputi kandungan zat gizi, kebersihan, campuran yang perlu ditambahkan, dan tidak boleh diradiasi (10). Selain itu, perlu dipertimbangkan pula tingkat penerimaan MPASI, karena menurut Nicklaus (11) bayi akan menerima MPASI dengan karakter 
tekstur lembut (sesuai dengan kemampuan pencernaannya), lebih menyukai rasa manis, menolak rasa pahit, dan menyukai rasa gurih yang diberi garam, serta menyukai flavor tergantung saat pertama kali diberi MPASI.

Penelitian ini bertujuan untuk membuat formulasi MPASI dengan penambahan HPIL, seleksi formula oleh ibu bayi, uji kesukaan oleh bayi, dan analisis kandungan gizi formula MPASI terbaik.

\section{BAHAN DAN METODE}

Jenis penelitian ini adalah eksperimental yang dibagi menjadi beberapa tahap utama, yaitu: produksi HPIL (hidrolisat protein ikan lele dumbo), formulasi bubur bayi, seleksi formula bubur bayi dengan uji kesukaan (panelis ibu bayi), uji penerimaan bubur oleh panelis bayi, dan uji nilai gizi bubur. Penelitian dilakukan di Laboratorium Biomedik dan Laboratorium Gizi Kuliner, STIKES Alma Ata Yogyakarta, Laboratorium Pangan Gizi, Pusat Studi Pangan dan Gizi (PSPG) Universitas Gadjah Mada (UGM), serta Laboratorium Latihan, Laboratorium Kimia dan Biokimia Pangan Fakultas Teknologi Pertanian, UGM, Yogyakarta. Untuk pengujian sensoris bayi dilaksanakan di Pondok Pesantren An-Nasyath, Sleman, Yogyakarta. Waktu penelitian dimulai bulan Juli 2013 hingga Desember 2013.

Bahan utama yang digunakan adalah lele dumbo yang dibeli dari pasar lokal di Yogyakarta. Untuk membuat hidrolisat protein ikan, dibutuhkan enzim papain (crude papain) yang diekstraksi dari getah buah papaya (Carica papaya) dengan pengeringan menggunakan larutan $\mathrm{Na}$-bisulfit $0,7 \%$. Untuk produksi HPIL menggunakan enzim papain yang diekstrak dari getah buah pepaya lokal, sedangkan HPIK diproduksi dari enzim komersial merk - paya. Untuk mengatur $\mathrm{pH}$ pada produksi hidrolisat digunakan $\mathrm{HCl} 1 \mathrm{M}$ dan $\mathrm{NaOH} 1 \mathrm{M}$.

\section{Produksi HPIL}

Enzim papain yang digunakan untuk menghidrolisis protein ikan lele diekstraksi dari getah (lateks) buah pepaya lokal dan dicampur dengan larutan Na-bisulfit 0,7\% (rasio lateks:air = $1: 4$ ), kemudian dikeringkan pada suhu $65^{\circ} \mathrm{C}$ selama
5-24 jam (12). Papain kering kemudian diayak dengan ayakan 100 mesh. Sebagai pembanding, digunakan enzim papain komersial merk PAYA.

Pembuatan hidrolisat protein ikan lele dumbo dibuat dengan berbagai macam enzim papain, antara lain crude papain (HPIL), papain komersial (HPIK), dan kontrol tanpa enzim (ILDU) menggunakan metode yang dikembangkan oleh Widadi (6) dengan sedikit dimodifikasi. Lele segar difilet, kulit dibuang, kemudian dicincang, dicampur dengan akuades (rasio daging: akuades 1:4), dan dicampur selama 2 menit. $\mathrm{pH} 7$ sebagai $\mathrm{pH}$ optimal diatur dengan $\mathrm{NaOH}$ $1 \mathrm{M}$ dan $\mathrm{HCl} 1 \mathrm{M}$. Lele kemudian dipre-inkubasi pada suhu $60^{\circ} \mathrm{C}$ selama 20 menit kemudian dihidrolisis dengan enzim papain $5 \%(\mathrm{~b} / \mathrm{v})$, suhu $60^{\circ} \mathrm{C}$ selama 6 jam. Untuk menghentikan reaksi hidrolisis, enzim diinaktivasi dengan pemanasan suhu $90^{\circ} \mathrm{C}$ selama 30 menit, kemudian disentrifugasi 5000 rpm selama 20 menit. Supernatan dikeringkan dengan spray dryer (suhu inlet $120^{\circ} \mathrm{C}$, outlet $84^{\circ} \mathrm{C}$ ). HPIL/HPIK diuji nilai rendemennya dengan membagi berat HPIL/HPIK dengan berat lele cincang.

\section{Formulasi bubur bayi}

Formula bubur bayi mengacu pada standar nasional Indonesia (SNI) 01-7111.1-2005 mengenai MP-ASI bubuk instan (10). Berdasarkan acuan tersebut, kandungan nilai gizi pada bubur bayi MP-ASI lemak minimal $6-15 \%$ dan protein $8-22 \%$. Formula basal bubur tanpa protein pada penelitian ini adalah $70 \%$ karbohidrat (25\% gula halus, $25 \%$ beras putih, dan $20 \%$ beras merah), $10 \%$ minyak kelapa sawit (sumber lemak), dan sisanya (20\%) merupakan gabungan dari protein, skim, garam, perisa, vanili. Pada penelitian ini dilakukan formulasi dengan mensubstitusi sumber protein standar (skim) dengan HPIL/HPIK. Formulasi dilakukan terutama atas dasar kemiripan rasa dengan standar bubur komersial. Substitusi HPIL/HPIK dibuat 100\%, 75\%, $50 \%$, dan $25 \%$, kemudian dipilih yang memiliki rasa paling baik. Formula bubur bayi dalam 100 gram disajikan pada Tabel 1.

\section{Seleksi formula bubur bayi}

Formula bubur bayi hasil formulasi diujikan kepada 23 ibu yang merupakan karyawan Universitas 
Tabel 1. Formula basal bubur bayi MP-ASI yang diperkaya protein hewani hipoalergenik dari ikan lele

\begin{tabular}{|c|c|c|c|c|}
\hline \multirow{2}{*}{$\begin{array}{c}\text { Bahan } \\
\text { (g) }\end{array}$} & \multicolumn{4}{|c|}{ Formula skim:HPIL/HPIK (\%) } \\
\hline & $A(75: 25)$ & B (50:50) & C (25:75) & $\mathrm{D}(0: 100)$ \\
\hline Beras putih & 25 & 25 & 25 & 25 \\
\hline Beras merah & 20 & 20 & 20 & 20 \\
\hline Gula halus & 25 & 25 & 25 & 25 \\
\hline Skim & 11,25 & 7,5 & 3,75 & 0 \\
\hline HPIL/HPIK & 3,75 & 7,5 & 11,25 & 15 \\
\hline Minyak sawit & 10 & 10 & 10 & 10 \\
\hline Garam,perisa, vanili & 5 & 5 & 5 & 5 \\
\hline Total & 100 & 100 & 100 & 100 \\
\hline
\end{tabular}

Alma Ata dengan kriteria inklusi: memiliki bayi berusia 6-24 bulan dan memiliki aktivitas menyuapi anaknya setiap hari. Uji kesukaan meliputi kesukaan keseluruhan dan kesukaan parsial (rasa, aroma, warna, tekstur, dan kekentalan) dengan skala penilaian 1-7, meliputi: $1=$ sangat tidak suka, $2=$ tidak suka, $3=$ agak tidak suka, $4=$ netral, $5=$ agak suka, $6=$ suka, $7=$ sangat suka.

Sebelum pelaksanaan seleksi, panelis diberikan pengarahan cara menilai. Untuk mengurangi tingkat kesalahan dalam pengujian rasa, panelis diminta makan crackers tawar dan air putih pada pergantian sampel yang diuji. Bubur dengan hasil uji panelis oleh ibu yang terbaik kemudian diujikan tingkat penerimaannya oleh bayi.

\section{Uji penerimaan bubur oleh panelis bayi}

Formula yang dipilih dari hasil uji kesukaan menggunakan panelis ibu kemudian diujikan kepada panelis bayi. Kriteria panelis bayi (inklusi) adalah berumur 6-12 bulan, dalam keadaan sehat, sudah pernah dan menerima konsumsi bubur bayi berbasis nasi (dari segi kesukaan dan tidak mengalami kelainan pencernaan), dan ibu bayi bersedia bayinya diikutkan dalam pengujian sensoris. Bayi tidak diikutkan dalam penelitian jika (kriteria eksklusi) sakit, termasuk mengalami gangguan pencernaan, sariawan, dan sakit gigi ataupun tidak mau diberi bubur saat pengujian. Bayi yang diundang untuk mengikuti uji sensoris sebanyak 15 bayi, namun yang datang 11 bayi dan data yang dapat digunakan hanya 9 bayi karena 1 bayi masih berusia 5 bulan dan 1 bayi tidur saat pengujian. Sebelum pengujian, ibu/pengasuh panelis diberi pengarahan tentang cara memberi penilaian tingkat penerimaan bubur oleh bayi. Penilaian dilakukan dengan melihat raut muka (tingkat kesukaan berdasar raut muka/facial hedonic) (13) dan atau ada tidaknya lepehan dari 2-3 suapan bubur. Skala raut muka ditampilkan pada Gambar 1.

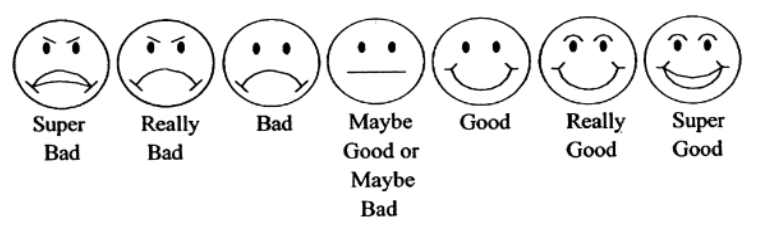

Gambar 1. Skala hedonik raut muka (13)

\section{Uji nilai gizi bubur MPASI}

Bubur bayi MPASI kemudian diuji nilai gizinya, meliputi uji kadar air, protein, lemak, dan abu (14). Kandungan karbohidrat ditentukan dengan by difference.

\section{Analisis data}

Data dianalisis menggunakan one way ANOVA dilanjutkan dengan uji Duncan untuk mengetahui hasil yang menunjukkan berbeda nyata. Kedua pengujian dilakukan menggunakan SPSS versi 16 .

\section{HASIL}

\section{Produksi HPIL/HPIK/ILDU}

Deskripsi bubur bayi dengan substitusi HPIL, HPIK, dan ILDU pada penelitian ini dapat dilihat pada Tabel 2. 
Tabel 2. Deskripsi produk HIPL/HPIK/ILDU

\begin{tabular}{lccc}
\hline Sampel & Warna & Tekstur & Rasa \\
\hline HPIL & Putih kehijauan & Berpasir & Asin, pahit \\
HPIK & Putih tulang & Halus & Asin \\
ILDU & Putih kecoklatan & Berpasir & Asin \\
\hline
\end{tabular}

Tabel 2 menunjukkan bahwa hidrolisis protein ikan lele dumbo yang dilakukan oleh enzim yang berbeda dapat menyebabkan perbedaan sifat fisik hidrolisat. Selain itu, lamanya waktu, suhu, dan $\mathrm{pH}$ juga berpengaruh terhadap beda sifat fisik, sehingga pada tingkat industri selayaknya hal ini dikendalikan.

\section{Formulasi bubur bayi}

Formulasi bubur MPASI dengan sumber protein dari skim dapat dibuat pada berbagai konsentrasi, namun substitusi HPIL hanya dapat dilakukan sampai konsentrasi $25 \%$ saja. Hal ini disebabkan penambahan sampai konsentrasi $>25 \%$ menyebabkan rasa pahit. Oleh karena itu, untuk keperluan uji kesukaan pada ibu disajikan sampel bubur dengan konsentrasi substitusi HPIL dan HPIK masing-masing sebesar $25 \%$

\section{Seleksi formula bubur bayi dengan uji kesukaan (panelis ibu bayi)}

Hasil uji kesukaan menggunakan panelis ibu, baik keseluruhan maupun parsial dapat dilihat pada Tabel 3. Berdasarkan Tabel 3, hasil uji keseluruhan, parsial rasa, dan aroma sebagian besar formula bubur disukai oleh panelis, kecuali formula skim:HPIL (75\%:25\%). Demikian pula dengan hasil uji parsial kelarutan yang tidak berbeda nyata pada semua sampel $(p>0,05)$, namun uji parsial warna HPIL dan HPIK diketahui kurang disukai dibandingkan dengan bubur komersial $(p<0,05)$.

\section{Uji penerimaan bubur oleh panelis bayi}

Pengujian dengan menggunakan panelis bayi pada penelitian ini menggunakan substitusi skim dengan HPIK (75\%:25\%). Adapun hasil uji kesukaan bayi dapat dilihat pada Tabel 4 .
Tabel 3. Hasil uji kesukaan keseluruhan dan parsial bubur bayi dengan panelis ibu

\begin{tabular}{|c|c|}
\hline Formula & Mean士SD \\
\hline \multicolumn{2}{|l|}{ Uji keseluruhan } \\
\hline Skim 100\% & $5,64 \pm 0,73^{a}$ \\
\hline Skim:HPIL(75\%:25\%) & $2,81 \pm 1,22^{b}$ \\
\hline Skim:HPIK(75\%:25\%) & $5,36 \pm 0,85^{a}$ \\
\hline Komersial & $5,09 \pm 1,41^{a}$ \\
\hline \multicolumn{2}{|l|}{ Uji parsial rasa } \\
\hline Skim $100 \%$ & $5,68 \pm 0,89^{a}$ \\
\hline Skim:HPIL(75\%:25\%) & $1,86 \pm 0,71^{b}$ \\
\hline Skim:HPIK(75\%:25\%) & $5,14 \pm 1,04^{a}$ \\
\hline Komersial & $5,18 \pm 1,37^{a}$ \\
\hline \multicolumn{2}{|l|}{ Uji parsial aroma } \\
\hline Skim $100 \%$ & $5,36 \pm 1,05^{a}$ \\
\hline Skim:HPIL(75\%:25\%) & $3,5 \pm 1,30^{b}$ \\
\hline Skim:HPIK(75\%:25\%) & $5,32 \pm 1,09^{a}$ \\
\hline Komersial & $5,14 \pm 1,08^{a}$ \\
\hline \multicolumn{2}{|l|}{ Uji parsial warna } \\
\hline Skim $100 \%$ & $4,64 \pm 1,22^{a}$ \\
\hline Skim:HPIL(75\%:25\%) & $4,04 \pm 1,36^{a}$ \\
\hline Skim:HPIK(75\%:25\%) & $4,27 \pm 1,35^{a}$ \\
\hline Komersial & $5,72 \pm 0,88^{b}$ \\
\hline \multicolumn{2}{|l|}{ Uji parsial tekstur } \\
\hline Skim $100 \%$ & $5,04 \pm 1,25^{a}$ \\
\hline Skim:HPIL(75\%:25\%) & $4,14 \pm 1,42^{b}$ \\
\hline Skim:HPIK(75\%:25\%) & $4,91 \pm 1,19 a b$ \\
\hline Komersial & $5,00 \pm 1,34^{a}$ \\
\hline \multicolumn{2}{|l|}{ Uji parsial kekentalan } \\
\hline Skim $100 \%$ & $4,91 \pm 1,57^{a}$ \\
\hline Skim:HPIL(75\%:25\%) & $4,14 \pm 1,46^{a}$ \\
\hline Skim:HPIK(75\%:25\%) & $4,86 \pm 1,36$ \\
\hline Komersial & $4,64 \pm 1,56^{a}$ \\
\hline
\end{tabular}

Keterangan:

HPIL(hidrolisat protein ikan lele dumbo dengan enzim papain kasar), HPIK (hidrolisat protein ikan lele dumbo dengan papain komersial)

Notasi yang berbeda pada satu kolom menyatakan berbeda nyata

Mean merupakan rata-rata skor 23 panelis dengan rentang nilai $1-7(1=$ sangat tidak suka, $2=$ tidak suka, $3=$ agak tidak suka, $4=$ netral, $5=$ agak suka, $6=$ suka, $7=$ sangat suka)

Tabel 4. Hasil uji kesukaan bubur bayi dengan panelis bayi

\begin{tabular}{lc}
\hline Kriteria penilaian & Jumlah panelis \\
\hline Sangat suka sekali & 2 \\
Suka sekali & 1 \\
Suka & 2 \\
Netral & 4 \\
\hline
\end{tabular}


Berdasarkan data pada Tabel 4, sebagian besar panelis bayi menerima bubur bayi formulasi menggunakan produk formula yang ditambah HPIK. Hal ini dapat dilihat tidak ada panelis yang menyatakan tidak suka dilihat dari skala raut muka dan tidak ada pula bayi yang melepeh bubur yang diberikan.

\section{Uji nilai gizi bubur}

Hasil uji proksimat sampel bubur dapat dilihat pada Tabel 5. Nilai gizi bubur, terutama protein paling tinggi terdapat pada bubur komersial, sedangkan kandungan protein bubur yang ditambahkan HPIL maupun HPIK pada konsentrasi yang sama tidak menyebabkan perbedaan kandungan protein. Kandungan lemak dan karbohidrat tertinggi terdapat pada bubur yang ditambah dengan HPIL. Kadar abu yang menyatakan jumlah mineral total paling banyak ditemukan pada bubur yang ditambah dengan protein dari skim.

\section{Tabel 5. Nilai gizi bubur MPASI}

\begin{tabular}{lc}
\hline \multicolumn{1}{c}{ Formula } & Konsentrasi (\%) \\
\hline Protein & $1,89 \pm 0,13^{\mathrm{a}}$ \\
Skim $100 \%$ & $2,73 \pm 0,02^{\mathrm{b}}$ \\
Skim:HPIL(75\%:25\%) & $2,57 \pm 0,09^{\mathrm{b}}$ \\
Skim:HPIK(75\%:25\%) & $12,55 \pm 0,25^{\mathrm{c}}$ \\
Komersial & \\
Lemak & $1,72 \pm 0,24^{\mathrm{a}}$ \\
Skim 100\% & $4,87 \pm 0,22^{\mathrm{b}}$ \\
Skim:HPIL(75\%:25\%) & $3,49 \pm 0,09^{\mathrm{c}}$ \\
Skim:HPIK(75\%:25\%) & $3,43 \pm 0,19^{\mathrm{c}}$ \\
Komersial & \\
Abu & $17,57 \pm 3,5^{\mathrm{a}}$ \\
Skim 100\% & $0,68 \pm 0,01^{\mathrm{b}}$ \\
Skim:HPIL(75\%:25\%) & $12,91 \pm 0,07^{\mathrm{a}}$ \\
Skim:HPIK(75\%:25\%) & $3,34 \pm 0,00^{\mathrm{b}}$ \\
Komersial & \\
Air & $4,09 \pm 0,12^{\mathrm{a}}$ \\
Skim 100\% & $4,22 \pm 0,02^{\mathrm{a}}$ \\
Skim:HPIL(75\%:25\%) & $4,95 \pm 0,08^{\mathrm{b}}$ \\
Skim:HPIK(75\%:25\%) & $3,60 \pm 0,11^{\mathrm{c}}$ \\
Komersial & \\
Karbohidrat & $74,73 \pm 3,01^{\mathrm{a}}$ \\
Skim 100\% & $89,28 \pm 0,27^{\mathrm{b}}$ \\
Skim:HPIL(75\%:25\%) & $76,08 \pm 0,24^{\mathrm{a}}$ \\
Skim:HPIK(75\%:25\%) & $77,07 \pm 0,12^{\mathrm{a}}$ \\
\hline Komersial &
\end{tabular}

Keterangan: Nilai diperoleh dari rata-rata 2 ulangan Notasi yang berbeda dalam 1 kolom menyatakan berbeda nyata

\section{BAHASAN}

\section{Produksi dan formulasi bubur bayi MPASI}

Produk hidrolisat HPIL pada penelitian ini berasa pahit dan ini merupakan salah satu kelemahan produk yang dihasilkan. Hal ini disebabkan adanya pemutusan ikatan peptida pada molekul protein yang dikatalisis oleh enzim papain sehingga menghasilkan beberapa peptida dengan berat molekul yang lebih kecil dan atau asam amino. Adapun asam amino yang berkontribusi terhadap rasa pahit, antara lain prolin dan peptida, aspargin, lysine, leusin, dan glisin (15). Rasa pahit juga dapat disebabkan oleh rantai cabang asam amino hidrofobik, seperti valin, isoleusin, fenilalanin, triptofan, leusin, and tirosin (9).

Banyaknya ikatan peptida yang diputuskan akibat proses hidrolisis dinyatakan dalam derajat hidrolisis (16). Berdasarkan penelitian Theodore (17), pada hidrolisis ikan lele, makin tinggi derajat hidrolisis protein, ditemukan senyawa protein dengan berat molekul besar yang makin sedikit dan protein dengan berat molekul kecil ( $<20 \mathrm{KDa}$ ) yang makin banyak. Pada pembuatan hidrolisat protein dengan bahan dasar ikan lele dumbo yang menggunakan enzim papain kasar diketahui memiliki derajat hidrolisis yang lebih tinggi dibandingkan dengan yang menggunakan enzim papain komersial, yaitu $49 \%$ dan $25 \%$ (8). Dengan demikian dapat diperkirakan bahwa protein dengan berat molekul kecil lebih banyak ditemukan pada HPIL dan hal inilah yang menjadi alasan produk HPIL berasa pahit, sedangkan produk HPIK maupun ILDU tidak berasa pahit. Hasil pengujian tingkat alergi produk hidrolisat protein ikan lele dumbo in vivo pada tikus dengan menggunakan enzim papain, diketahui bahwa produk hidrolisat dapat mengurangi tingkat alergi dibandingkan dengan produk protein yang tidak dihidrolisis (8).

Pada penelitian ini, substitusi skim protein hanya bisa dilakukan sampai konsentrasi $25 \% \mathrm{HPIL}$, karena makin banyak HPIL yang terdapat dalam bubur, makin terasa pahitnya. Tingkat kepahitan $>25 \%$ dirasa tidak layak untuk diberikan kepada panelis. 


\section{Seleksi formula bubur bayi dengan uji kesukaan (panelis ibu bayi)}

Pada penelitian ini, secara keseluruhan, bubur bayi yang ditambah dengan HPIL paling tidak disukai oleh panelis ibu bayi, begitu pula dengan hasil uji parsial rasa, aroma, dan tekstur. Hal ini disebabkan bubur berasa pahit akibat adanya penambahan produk hidrolisat protein. Hidrolisis protein menggunakan enzim menyebabkan pemecahan protein menjadi molekul dengan berat molekul yang lebih rendah, sehingga pada produk hidrolisat protein mengandung peptida atau asam amino dengan berat molekul rendah. Rantai cabang asam amino hidrofobik seperti valin, isoleusin, fenilalanin, triptofan, leusin, and tirosin menyebabkan rasa pahit (9). Jumlah asam amino tersebut dapat menjadi lebih banyak apabila derajat hidrolisis tidak terkendali (9). Berdasarkan penelitian Theodore (17), pada hidrolisis ikan lele, makin tinggi derajat hidrolisis protein, ditemukan senyawa protein dengan berat molekul besar yang makin sedikit dan protein dengan berat molekul kecil $(<20 \mathrm{KDa})$ yang makin banyak. Pada penelitian ini, HPIL dihasilkan melalui hidrolisis enzim papain kasar yang memiliki derajat hidrolisis $49 \%$ dan HPIK menggunakan enzim papain komersial dengan derajat hidrolisis $25 \%$ (8). Derajat hidrolisis HPIL yang lebih tinggi dibanding HPIK menyebabkan lebih banyak dihasilkan protein, peptida, atau asam amino dengan berat molekul rendah. Hal ini menyebabkan HPIL kemungkinan besar mengandung lebih banyak rantai asam amino hidrofobik yang berakibat munculnya rasa pahit.

Hasil uji parsial warna membuktikan bahwa warna produk bubur bayi komersial lebih disukai oleh konsumen dibandingkan dengan produk hidrolisat. Hal ini disebabkan HPIL, HPIK, maupun ILDU memiliki warna masing-masing putih kehijauan, putih tulang, dan kecoklatan (Tabel 2), sehingga penambahannya ke bubur mempengaruhi warna dan menyebabkan kurang disukai panelis. Hasil uji kekentalan bubur tidak dipengaruhi oleh jenis sumber protein yang ditambahkan. Semua sampe memiliki nilai kekentalan yang sama.

Beberapa penelitian lain juga membuktikan tingkat penerimaan yang baik pada formulasi bubur bayi dengan peningkatan protein, seperti penelitian di Nigeria yang menambahkan tempe ke formula berbasis tepung ogi (dari maizena yang difermentasi) (2), bubur dari tepung berbasis kedelai dengan fermentasi (18).

\section{Uji penerimaan bubur oleh panelis bayi}

Hasil penelitian ini membuktikan bahwa bubur dengan formula penambahan HPIK dapat diterima oleh bayi. Hal ini dapat dilihat dari banyaknya suapan yang tidak menyebabkan muntah ataupun dilepeh kembali oleh bayi. Bayi akan menerima MPASI dengan karakter tekstur lembut (sesuai dengan kemampuan pencernaannya), lebih menyukai rasa manis, menolak rasa pahit, dan menyukai rasa gurih yang diberi garam, serta menyukai flavor tergantung saat pertama kali diberi MPASI. Di samping sifat sensoris produk, beberapa hal juga menentukan tingkat penerimaan MPASI oleh bayi, antara lain: usia pertama kali dikenalkan MPASI, pengulangan pemberian suatu makanan, dan variasi makanan yang diberikan (11). Dengan demikian pembuatan formula bubur bayi yang bervariasi penting untuk meningkatkan asupan makanan pada bayi.

\section{Uji nilai gizi bubur}

Kandungan protein pada bubur komersial paling tinggi. Hal ini dipengaruhi jumlah protein yang ditambahkan. Pada bubur komersial, penambahan skim dapat dilakukan sampai konsentrasi tinggi, namun pada industri biasanya penambahan dibatasi oleh harga pokok produksi. Makin tinggi protein yang ditambahkan, maka makin tinggi harga pokok produksinya. Pada bubur formulasi dengan HPIL maupun HPIK, jumlah protein yang ditambahkan tidak dapat lebih dari $25 \%$ karena di atas konsentrasi tersebut dapat menyebabkan rasa pahit. Tujuan utama penelitian ini adalah menambahkan kandungan protein pada bubur bayi, namun produk formula HPIL dan HPIK hanya terkandung 2,73 dan $2,57 \%$ protein. Hal ini berbeda dengan hasil penelitian lain yang melaporkan kandungan protein yang lebih tinggi. Pada penelitian Amankwah et al. (19) diketahui adanya penambahan $4,14 \%$ ikan giling kering mampu menambah protein hingga $19,13 \%$. Dibandingkan dengan hasil tersebut, penambahan hidrolisat protein ikan lele pada bubur 
MPASI belum dapat meningkatkan kandungan protein di dalam produk tersebut karena adanya keterbatasan jumlah yang dapat ditambahkan ke produk akibat rasa pahit yang dihasilkan.

Pada formula bubur bayi yang menggunakan ubi dengan penambahan protein nabati sebesar $40 \%$ (kacang tolo dan kacang tanah) mampu meningkatkan kadar protein pada produk sebesar 18-38\% (20). Dari segi jumlah, penambahan protein nabati tersebut mampu meningkatkan kandungan protein yang lebih tinggi pada bubur dibandingkan dengan penambahan hidrolisat protein ikan lele dumbo. Namun demikian, nilai cerna bisa lebih tinggi pada produk hewani dibanding nabati (5).

Ukuran sajian produk formula ini adalah 15 gram. Berdasarkan hasil uji proksimat, kandungan protein dalam 15 gram produk HPIL dan HPIK tidak berbeda nyata $(p>0,05)$, masing-masing sebesar 0,41 gram dan 0,39 gram. Jika bayi berumur 7-11 bulan mengonsumsi bubur 2 kali sehari, maka jumlah protein yang dapat dikonsumsi sebesar 0,82 gram dan 0,78 gram. Jumlah tersebut dapat memenuhi 4,5\% dan 4,3\% AKG (21). Jumlah ini masih jauh dibanding dengan bubur komersial yang pada penelitian ini dapat memenuhi 20,91\% AKG dengan mengonsumsi dua porsi sajian.

Walaupun kandungan protein dari produk HPIL dan HPIK cukup rendah dibandingkan dengan bubur komersial, namun kandungan lemak dan karbohidrat HPIL cukup tinggi dan berbeda nyata dibanding produk komersial dan HPIK. Dengan konsumsi 2 kali bubur HPIL (berat per sajian $15 \mathrm{~g}$ ), maka dapat memenuhi $32,6 \%$ (26,784 gram) AKG untuk karbohidrat dan $4,1 \%$ AKG (1,461 gram) untuk lemak. Pada produk bubur komersial, mampu memenuhi 28,2\% AKG untuk karbohidrat dan 2,8\% AKG untuk lemak. Angka tersebut menunjukkan bahwa penambahan HPIL justru meningkatkan kandungan lemak dan karbohidrat pada bubur bayi.

\section{KESIMPULAN DAN SARAN}

Proses hidrolisis kimiawi protein menggunakan enzim papain, baik menggunakan enzim papain kasar maupun enzim papain komersial pada ikan lele dumbo menyebabkan perubahan warna, rasa, dan aroma produk. Adanya perubahan sifat tersebut menyebabkan penambahannya ke dalam formulasi bubur MPASI hanya sampai kadar $25 \%$. Di atas kadar tersebut, produk berasa pahit. Hasil uji sensoris produk formulasi HPIK dapat diterima oleh panelis ibu dan bayi, sedangkan produk HPIL tidak. Kandungan protein produk formulasi lebih rendah dibanding bubur komersial, namun kandungan karbohidrat dan lemak lebih tinggi.

Untuk dapat mengembangkan produk hidrolisat, perlu dilakukan penelitian berkaitan dengan optimasi proses hidrolisis sehingga bisa mengurangi rasa pahit. Pengurangan rasa pahit ini dapat meningkatkan jumlah produk hidrolisat yang bisa ditambahkan ke dalam produk, sehingga mampu meningkatkan kandungan protein dalam produk. Selain itu, perlu pula diuji tingkat kecernaan protein di dalam produk untuk mengetahui kualitas protein produk.

\section{UCAPAN TERIMA KASIH}

Peneliti mengucapkan terima kasih kepada Direktorat Jenderal Pendidikan Tinggi Kementerian Pendidikan dan Kebudayaan yang telah mendukung pendanaan penelitian ini.

\section{RUJUKAN}

1. Badan Penelitian dan Pengembangan Kesehatan Kementerian Kesehatan Republik Indonesia. RISKESDAS 2010. Jakarta; 2010.

2. Osundahunsi OF, Aworh OC. A preliminary study on the use of tempe-based formula as a weaning diet in Nigeria. Plant Foods Hum Nutr. 2002;57:365-76.

3. Babajide JM, Babajide SO, Uzochukwu S. Cassava-soy weaning food: Biological evaluation and effects on rat organs. Plant Foods Hum Nutr. 2001;56:167-73.

4. Wadud S, Abid H, Ara H, Kosar S, Shah WH. Production, quality evaluation and storage stability of vegetable protein-based baby foods. 2004;85:175-9.

5. Hoffman JR, Falvo MJ. Protein-which is best? J Sport Sci Med. 2004;3:118-30. 
6. Widadi IR. Pembuatan dan karakterisasi hidrolisat protein dari ikan lele dumbo (Clarias gariepinus) menggunakan enzim papain. Institut Pertanian Bogor; 2011.

7. Ersoy B, Yılmaz AB. Frozen storage of African catfish (Clarias gariepinus BURCHELL, 1822) mince balls. Turkish J Vet Anim Sci. 2003;27:827-32.

8. Aprilia V, Hati FS. Use of Crude and Commercial Papain for the Hydrolysis of Catfish ( Clarias gariepinus ) Protein to Reduce Allergenicity. The 16th Food Innovation Asia Conference 2014 [Internet]. Bangkok, Thailand; 2014. p. 34-43. Available from: agkb.lib.ku.ac.th/ku/ search_detail/dowload_digital_file/22673/34

9. Nilsang S, Lertsiri S, Suphantharika M, Assavanig A. Optimization of enzymatic hydrolysis of fish soluble concentrate y commercial proteases. J Food Eng. 2005;70:571-8.

10. Nasional BS. SNI Makanan Pendamping Air Susu Ibu (MP-ASI)-Bagian 1: Bubuk Instan. Jakarta; 2005.

11. Nicklaus S. Children's acceptance of new foods at weaning . Role of practices of weaning and of food sensory properties. Appetite [Internet]. Elsevier Ltd; 2011;57(3):812-5. Available from: http://dx.doi.org/10.1016/j.appet.2011.05.321

12. Winarti S, Jariyah, Purnomo Y. Proses pembuatan VCO (virgin coconut oil) secara enzimatis menggunakan papain kasar. J Teknol Pertan. 2007;8(2):136-41.

13. Guinard J. Sensory and consumer testing with children. Trends Food Sci Technol 11. 2001;11:273-83.
14. AOAC. Official of analysis of the association of official analytical chemistry. Airlington: AOAC Inc.; 1995.

15. Tanuja S, Viji P, Zynudheen AA, Joshy CG. Composition, functional properties and antioxidative activity of hydrolysates prepared from the frame meat of Striped catfish (Pangasianodon hypophthalmus). Egypt J Biol. 2012;14:27-35.

16. Rutherfurd SM. Methodology for determining degree of hydrolysis of protein hydrolysates: a review. J AOAC Int. 2010;93(5):1515-22.

17. Theodore ANNE. Bioactive and functional properties of catfish protein hydrolysates and catfish protein isolates. University of Florida; 2005.

18. Sanni AI, Onilude AA, Ibidapo OT. Biochemical composition of infant weaning food fabricated from fermented blends of cereal and soybean. Food Chem. 1999;65:35-9.

19. Amankwah EA, Barimah J, Nuamah AKM, Oldham JH, Nnaji CO. Formulation of weaning food from fermented maize, rice, soybean and fishmeal. Pakistan J Nutr. 2009;8(11):174752.

20. Adenuga W. Nutritional and sensory profiles of sweet potato based infant weaning food fortified with cowpea and peanut. J Food Technol. 2010;8(5):223-8.

21. Menteri Kesehatan Republik Indonesia. Peraturan Menteri Kesehatan Republik Indonesia Nomor 75 Tahun 2013 tentang Angka Kecukupan Gizi yang Dianjurkan bagi Bangsa Indonesia. Jakarta; 2013. 